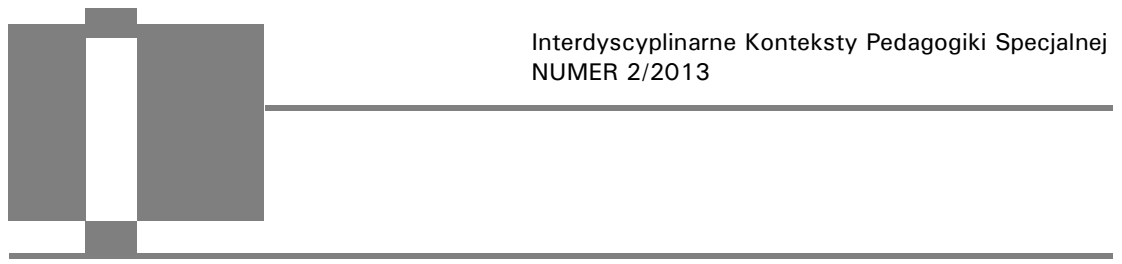

\title{
Recenzja książki Zenona Gajdzicy pt. Kategorie sukcesów w opiniach nauczycieli klas integracyjnych jako przyczynek do poszukiwania koncepcji edukacji integracyjnej, Oficyna Wydawnicza Impuls, Kraków 2013
}

Przedmiotem niniejszej recenzji jest najnowsza książka Zenona Gajdzicy pt. Kategorie sukcesów w opiniach nauczycieli klas integracyjnych jako przyczynek do poszukiwania koncepcji edukacji integracyjnej. To bardzo wartościowa pozycja wydawnicza, wypełniająca lukę w obrębie opracowań na temat edukacji integracyjnej. Stanowi podsumowanie dużego projektu badawczego, który miał na celu ukazanie całościowego obrazu sytuacji nauczycieli klas integracyjnych. Jest kontynuacją i dopełnieniem innej publikacji tego autora $^{1}$, poruszającej problemy edukacji integracyjnej, które są punktem odniesienia dla poszukiwania mocnych stron. Jak wskazuje sam tytuł opracowania, podstawę rozważań stanowią kategorie pozytywne, czyli sukcesy integracyjnej formy kształcenia.

Edukację integracyjną traktuje się jako formę pośrednią pomiędzy pedagogiką a pedagogiką specjalną. Jak dotąd nie sformułowano jej solidnych podstaw teoretycznych. Nie da się ukryć, że ma ona specyficzne właściwości i uwarunkowania, co wynika m.in. z ogromnego bogactwa zmiennych występujących $\mathrm{w}$ tej formie kształcenia oraz $\mathrm{z}$ interdyscyplinarności, będącej podstawą samej koncepcji. Dotychczasowe opracowania

1 Z. Gajdzica, Sytuacje trudne w opiniach nauczycieli klas integracyjnych, Oficyna Wydawnicza Impuls, Kraków 2011. 
na ten temat mają charakter praktycznych prezentacji modeli lub teoretycznych refleksji nad podstawami edukacji integracyjnej. Celem badań Z. Gajdzicy było skonstruowanie kategorii teoretycznych tej formy edukacji. Autor szukał drogi do jego realizacji poprzez pośrednią metodę badania rzeczywistości, czyli analizę opinii nauczycieli, którzy są zarówno realizatorami, jak i kreatorami integracyjnej rzeczywistości.

Praca nie ma klasycznej formy trójdzielnej. Jej układ jest nietypowy dla opracowań naukowych. Zrezygnowano w niej z umieszczenia na początku obszernej analizy teoretycznej. Zastosowano też odmienną drogę dochodzenia do wiedzy - nie wyprowadzono wniosków dla praktyki z teorii, lecz postąpiono odwrotnie. Wypowiedzi praktyków stały się podstawami do konstruowania teorii. Nie znaczy to, że autor nie korzystał w ogóle $\mathrm{z}$ dotychczasowego dorobku badawczego w zakresie edukacji integracyjnej. Odniósł się do niego w toku analizy materiału empirycznego. Zabieg ten miał na celu uniknięcie przedzałożeniowości, która jest niewskazana $\mathrm{w}$ badaniach prowadzonych metodą teorii ugruntowanej. Decydujący się na nią badacz oczekuje, że kategorie teoretyczne zostaną wygenerowane przez samych badanych.

Rozdział IV poświęcono metodologii. Autor w sposób klarowny i przekonujący uzasadnił wybór dwóch metod: badania fokusowego oraz wywiadu narracyjnego. Metodologię wywiedziono z założeń teorii ugruntowanej, a badania miały charakter praktyczny. Chodziło o rozpoznanie i rozpatrzenie konkretnych problemów praktycznych. Taki dobór metody był związany z tym, że sukces stanowi kategorię bardzo trudną do zdefiniowania oraz obiektywnego zmierzenia. Zastosowano technikę fokusową. Skoncentrowano się na trzech grupach nauczycieli, wyróżnionych z uwzględnieniem następujących zmiennych: wielkość szkoły, liczba oraz tradycja klas integracyjnych $\mathrm{w}$ danej placówce. Pozwoliło to na porównania. Ze względu na ograniczenia metody fokusowej badania zostały uzupełnione wywiadami narracyjnymi, co umożliwiło badaczowi uzyskanie złożonych, wielowątkowych wypowiedzi nauczycieli, które stały się podstawami do wnikliwej analizy jakościowej.

Badania Z. Gajdzicy pozwalają zdefiniować sukcesy szkolnictwa integracyjnego $\mathrm{w}$ kilku kategoriach. Pierwszą $\mathrm{z}$ nich jest organizacja środowiska wielostronnego rozwoju dziecka $\mathrm{z}$ niepełnosprawnością przy zachowaniu struktury społecznej szkoły zbliżonej do struktury społeczeństwa. Za wskaźnik takiego sukcesu przyjmuje się zapewnienie możliwości poddania dziecka terapii kompleksowej na tyle, by nie musiało ono korzystać 
z dodatkowych usług poza szkołą. Wiąże się to z utworzeniem wieloprofesjonalnego zespołu specjalistów w placówce oraz jej dobrym zaopatrzeniem w sprzęt specjalistyczny. Sukcesami są również: zadowolenie rodziców, ich pozytywne opinie o placówce oraz dobre nastawienie do idei integracji, wyrażające się m.in. w dużym zaangażowaniu $\mathrm{w}$ życie szkoły oraz we współpracę z nauczycielami. Istotną rolę odgrywa też prawidłowy dobór uczniów $\mathrm{w}$ ramach klasy integracyjnej. Ważne wskaźniki sukcesu stanowią również: niewielka liczebność klas, pozwalająca na lepsze poznanie uczniów przez nauczyciela, dobra atmosfera i klimat klasy oraz pozytywne relacje interpersonalne. Druga kategoria wiąże się z osiągnięciami dziecka. Obejmuje poprawę jego funkcjonowania w różnych obszarach rozwoju, osiąganie przez nie celów rehabilitacyjnych, nabywanie nowych umiejętności i kształtowanie jego sprawności. Mocno akcentowanym aspektem było uzyskiwanie dobrych wyników w testach kompetencji wśród uczniów klas integracyjnych. Jako sukcesy społeczne określono efektywną socjalizację uczniów z orzeczeniem o potrzebie kształcenia specjalnego oraz nawiązywanie przez nich symetrycznych relacji z innymi dziećmi w klasie. Kolejną kategorię sukcesu stanowi dobra reputacja szkoły. Prestiż łączy się z osiąganiem wysokich efektów kształcenia, zatrudnianiem specjalistów wysokiej klasy, licznymi sukcesami uczniów oraz dobrą opinią w środowisku na temat ogólnego funkcjonowania i organizacji pracy szkoły. Piątą kategorię sukcesów wyróżnioną w toku badań autor wiąże z rozwojem zawodowym i osobowym nauczycieli szkoły integracyjnej. Badania pokazują, że jest to miejsce stwarzające dogodne warunki do zaspokajania ambicji oraz aspiracji nauczycieli, co pociąga za sobą osiąganie przez nich satysfakcji zawodowej.

Autor doszedł do wniosku, że sposób definiowania przez nauczycieli pojęcia sukcesu pozwala na wskazanie preferowanej przez nich koncepcji edukacji integracyjnej. Temu zagadnieniu został poświęcony VI rozdział książki, w którym Z. Gajdzica dokonał próby ukonstytuowania teorii wyprowadzonej $\mathrm{z}$ wypowiedzi nauczycieli. W efekcie tej analizy powstały dwie koncepcje edukacji integracyjnej. Jedna z nich, określona jako „integracja rehabilitacyjna", ma u podstaw przekonanie o nadrzędnej roli rehabilitacji w procesie integracji szkolnej uczniów z niepełnosprawnością. Jej korzenie sięgają tradycji pedagogiki specjalnej z lat 70. Koncepcja ta zasadza się na definiowaniu niepełnosprawności przez pryzmat braku, uszkodzenia lub defektu. $W$ tym podejściu pierwszeństwo mają cele rehabilitacyjne, co niesie ze sobą ryzyko negatywnych następstw w postaci redukcji 
podmiotowości osoby, nadmiernego skupienia się na jej usprawnianiu oraz "organizowaniu jej życiorysu pod dyktando procesów korygowania i usprawniania" 2 . Drugą kategorią teoretyczną sformułowaną na podstawie badań jest „integracja uspołeczniająca”. Wpisuje się ona w nowoczesną społeczną koncepcję myślenia o niepełnosprawności. Stanowi efekt porzucenia myślenia nozologicznego na rzecz funkcjonalnej terminologii opisującej niepełnosprawność jako wynik pewnych negatywnych uwarunkowań społecznych, ekonomicznych, kulturowych, religijnych itd. Głównym aspektem odróżniającym ją od integracji rehabilitacyjnej jest skupienie się na jakości relacji interpersonalnych $\mathrm{w}$ grupie rówieśniczej oraz osiąganiu dobrego samopoczucia przez dziecko. Niepełnosprawność traktuje się jako jedną z cech osoby, a jej znaczenia nie uznaje się za pierwszoplanowe. Rehabilitacja odgrywa rolę służebną wobec edukacji, co jednak nie oznacza umniejszania jej znaczenia. Stanowi immanentną część wkomponowaną w całość procesu edukacji pomiędzy potrzeby zespołu klasowego a uspołecznienie. Główne źródło wsparcia dla ucznia to nauczyciel, podczas gdy w koncepcji integracji rehabilitacyjnej źródło to stanowią specjaliści. Tego typu integracja jest zdecydowanie bliższa koncepcji edukacji włączającej, co można wywnioskować na podstawie licznych opracowań poświęconych tej tematyce ${ }^{3}$.

Książka Z. Gajdzicy stanowi ważny głos w dyskusji o tym, jaka jest i jaka powinna być polska edukacja integracyjna. W publikacji został poruszony ważny wątek relacji pomiędzy pedagogiką a pedagogiką specjalną, wywołujący wiele emocji w środowisku osób zajmujących się oświatą. Jak wynika z badań autora, przekonanie o prymacie edukacji specjalnej nad ogólną ma poważne konsekwencje, ponieważ warunkuje kształt integracji - ukierunkowuje ją w stronę integracji rehabilitacyjnej. Z kolei uznanie, że odgrywa ona rolę wspierającą, sprzyja urzeczywistnianiu integracji uspo-

${ }^{2}$ Idem, Kategorie sukcesów w opiniach nauczycieli klas integracyjnych jako przyczynek do poszukiwania koncepcji edukacji integracyjnej, Oficyna Wydawnicza Impuls, Kraków 2013, s. 120.

${ }^{3}$ Warto przywołać chociażby następujące opracowania: Within walls without boundaries. Handbook on Inclusive Education for educators, administrators and planners, red. M. Puri, G. Abraham, Sage Publications, New Delhi 2004; G. Szumski, Integracyjne kształcenie niepetnosprawnych, Wydawnictwo Naukowe PWN, Wydawnictwo APS, Warszawa 2006; pozycje wydawane przez UNESCO, m.in.: Toward inclusive education for children with disabilities, Bangkok 2009; Policy guidlines on inclusion in education, Paris 2009. 
łeczniającej. Trudno ocenić, którą z form należy uznać za bardziej właściwą. Autor nie dokonuje wartościowania, co jest bardzo cenne, ponieważ dzięki temu czytelnik ma pole do własnych przemyśleń. Jeżeli przyjmie się, że w procesie edukacji i rehabilitacji najistotniejsze role zawsze odgrywają indywidualizacja oddziaływań oraz wnikliwa analiza konkretnego przypadku, wybór formy integracji dla konkretnego dziecka również powinien zostać poddany starannej refleksji.

\section{Bibliografia}

GAJDZICA Z., Kategorie sukcesów w opiniach nauczycieli klas integracyjnych jako przyczynek do poszukiwania koncepcji edukacji integracyjnej, Oficyna Wydawnicza Impuls, Kraków 2013.

GAJDZICA Z., Sytuacje trudne w opiniach nauczycieli klas integracyjnych, Oficyna Wydawnicza Impuls, Kraków 2011.

SZUMSKI G., Integracyjne ksztatcenie niepetnosprawnych, Wydawnictwo Naukowe PWN, Wydawnictwo APS, Warszawa 2006.

UNESCO, Policy guidlines on inclusion in education, Paris 2009.

UNESCO, Toward inclusive education for children with disabilities, Bangkok 2009.

Within walls without boundaries. Handbook on Inclusive Education for educators, administrators and planners, red. M. Puri, G. Abraham, Sage Publications, New Delhi 2004. 